\title{
Salinity preference of silvering Japanese eel Anguilla japonica: evidence from pituitary prolactin mRNA levels and otolith Sr:Ca ratios
}

\author{
Yu San Han ${ }^{1}$, John Yu Lin Yu' ${ }^{2}$ I Chiu Liao ${ }^{3}$, Wann Nian Tzeng ${ }^{1, *}$ \\ ${ }^{1}$ Institute of Zoology, College of Life Science, National Taiwan University, Taipei, Taiwan, ROC \\ ${ }^{2}$ Endocrinology Laboratory, Institute of Zoology, Academia Sinica, Taipei, Taiwan, ROC \\ ${ }^{3}$ Taiwan Fisheries Research Institute, 199 Hou-Ih Road, Keelung, Taiwan, ROC
}

\begin{abstract}
The salinity preference of Japanese eel Anguilla japonica during silvering was validated from the viewpoints of physiological ecology by examining the pituitary prolactin (PRL) mRNA expression and the otolith strontium:calcium $(\mathrm{Sr}: \mathrm{Ca})$ ratios of the eels of different sexual maturity stages collected in an estuary of Taiwan. The PRL possessed a putative signal peptide of 24 amino acids and a mature peptide of 185 amino acids. RT-PCR and real-time quantitative PCR analyses indicated that the transcript levels of PRL mRNA significantly decreased from yellow to silver stage. On the contrary, the Sr:Ca ratios at the otolith edge of silver eels, which recorded their latest experience of salinity history, significantly increased. The increase in otolith $\mathrm{Sr}$ :Ca ratios and the decrease in PRL mRNA expression are consistent with the timing of migration from freshwater to seawater during silvering of the eel.
\end{abstract}

KEY WORDS: Japanese eel $\cdot$ Salinity preference $\cdot$ Otolith $\cdot$ Sr:Ca ratio $\cdot$ Prolactin $\cdot$ mRNA $\cdot$ Silvering

\section{INTRODUCTION}

Japanese eel Anguilla japonica Temminck and Schlegel is a catadromous fish that spawns in the waters of the west Mariana Islands (Tsukamoto 1992) and grows in estuarine and freshwater habitats of northern East Asia (Tesch 1977). Developmental stages of the eel include: egg, leptocephalus, glass eel, elver, yellow, and silver eel stages. The eel lives in rivers for approximately 5 to $8 \mathrm{yr}$ during growth-phase yellow stage (Tzeng et al. 2000a), and undergoes a drastic change in morphology and physiology during metamorphosing from yellow to silver eel stage (silvering) (Tesch 1977, Lokman \& Young 1998a,b, Han et al. 2003). During silvering, the eel changes its skin color from white/yellow to silver on the belly and from green to black on the back, migrates downstream, and rapidly develops gonads (Matsui 1972, Pankhurst 1982, Pankhurst \& Sorensen 1984, Jessop 1987, Sorensen \& Pankhurst 1988). The silver eel then migrates back to the ocean to spawn and die (Tesch 1977).
At silvering, the eel is expected to go through some physiological changes and use osmoregulation for spawning migration from freshwater to seawater. However, except for the conventional telemetric and hydroacoustic trackings on the short-term movement and migratory behavior of the yellow or silver eels (Westin 1990, Aoyama et al. 1999a,b, McCleave \& Arnold 1999), no study has been done on the migratory behavior, associated physiological changes, and environmental requirements of the eel during silvering. Accordingly, it is necessary to establish an effective method to better understand the migratory behavior of the eel during silvering.

Strontium:calcium (Sr:Ca) ratios in otoliths, in combination with age data, are widely used to reconstruct the environmental history of fish migrating between freshwater and seawater (Radtke \& Shafer 1992, Otake et al. 1994, Tzeng \& Tsai 1994, Tzeng 1996, Tzeng et al. 1997, $2002 b, 2003)$. This is because the concentration of strontium ( $\mathrm{Sr}$ ) is approximately 100 -fold greater in seawater than in freshwater, and the $\mathrm{Sr}$ :Ca ratios in otoliths 
are positively correlated to ambient salinity (Tzeng et al. 1996, Campana 1999). Recent studies have indicated that the migratory behavior of the eel is more flexible and complicated than previously believed. The freshwater eels, e.g. European and Japanese eels, may skip the freshwater habitat and live in marine coastal waters until maturation (Tzeng et al. 1997, 2000b, 2003, Tsukamoto et al. 1998, Tsukamoto \& Arai 2001). Jessop et al. (2002) also indicates that some American eels in the growth-phase yellow stage irregularly migrate between freshwater and estuary. Accordingly, the Sr:Ca ratios in otoliths may have the potential to explore the migratory behavior of the eel during silvering.

The osmoregulatory hormone prolactin (PRL) is an important indicator to understand when the fish migrates between freshwater and seawater. PRL is a polypeptide hormone secreted by lactotropic cells of the anterior pituitary gland. In euryhaline fishes, PRL can maintain a hydromineral balance during freshwater adaptation (Clarke \& Bern 1980). In the seabream, PRL treatment can increase the blood $\mathrm{Cl}^{-}$concentration, and decrease both the branchial $\mathrm{Na}^{+}-\mathrm{K}^{+}$-ATPase activity and the numbers of the chloride cells in the gill which actively excrete interior $\mathrm{Na}^{+}$and $\mathrm{Cl}^{-}$to the seawater (Kelly et al. 1999). The water drinking behavior of the Japanese eel is inhibited by injecting PRL (Kozaka et al. 2003). These modifications in response to PRL treatment can promote the freshwater adaptation of the fish. In hypophysectomized killifish, PRL treatment can retain plasma $\mathrm{Na}^{+}$when fish are transferred from seawater to freshwater (Suzuki et al. 1991a). The PRL levels in the plasma and pituitary gland of the Japanese eels are significantly lower in those adapted to seawater than freshwater, but increase significantly after the eels are transferred from seawater to freshwater (Suzuki \& Hirano 1991). The PRL level in response to salinity is reversible. A similar pattern is also found in the European eel (Quérat et al. 1994). In vitro studies also indicate that the secretion of PRL by organ-cultured teleost pituitaries is activated in a hypotonic medium (Ingleton et al. 1973, Nagahama et al. 1975, Benjamin \& Baker 1976, Suzuki et al. 1991b). Thus, the level of pituitary PRL is a possible candidate for monitoring the salinity preference of the wild eels during silvering.

This study aims to integrate the PRL transcript levels and the otolith Sr:Ca ratios of the eel at different developmental stages to better understand the salinity preference of the wild Japanese eel during silvering.

\section{MATERIALS AND METHODS}

Study organisms. The Japanese eels were collected by eel pots in the Kaoping River estuary in SW Taiwan $\left(120^{\circ} 50^{\prime} \mathrm{E}\right.$ and $22^{\circ} 40^{\prime} \mathrm{N}$, Fig. 1) during the period from 1999 to 2001 . The eel pots were set on the riverbed in the estuary, which is influenced by a tidal cycle with a salinity from $0 \mathrm{ppt}$ in the ebb tide to $30 \mathrm{ppt}$ in the flood tide. The eel pots were set in the day-time ebb tide and the eels were collected in the next ebb tide over approximately $24 \mathrm{~h}$. The eels were trapped in the eel pots when foraging at night-time. The maturity stages of the wild females before and during silvering were divided into 3 categories, yellow, pre-silver and silver, based on skin color and oocyte diameter as described in the previous study (Han et al. 2003). Because the occurrence of eels in different stages is seasondependent for the pre-silver and silver eels (Han et al. 2003), the silver females were caught in the winter (November to February), while the pre-silver females were caught in summer and autumn (June to October). The yellow females were caught all year around.

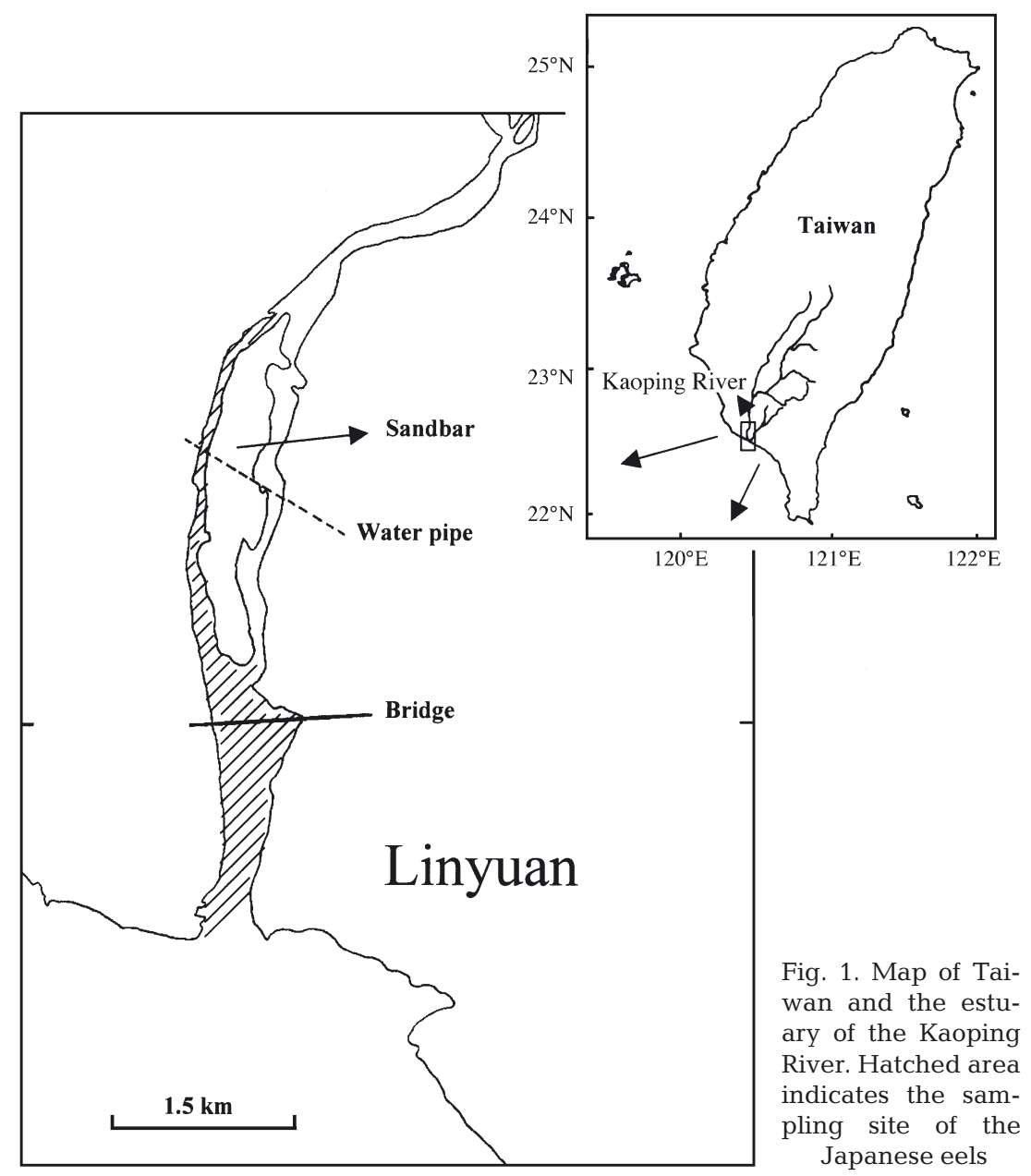


After collection, the eel was stunned with ice and immediately transferred to the lab for processing. The total length (TL, $\pm 0.1 \mathrm{~cm})$, body weight (BW, $\pm 0.1 \mathrm{~g}$ ), and horizontal and vertical diameters $( \pm 0.01 \mathrm{~mm})$ of the left eye of the eel were measured, and their otoliths were collected. The ocular index (OI) is a measure of the ratio of eye area to total length of the eel (Pankhurst 1982), and was calculated as OI = $[(A+B) / 4]^{2} \times \pi / \mathrm{TL} \times 100$, where $A$ and $B$ are horizontal and vertical diameters of the left eye, respectively. The sex of each eel was determined by histology of the gonad. The gonad weight $(\mathrm{GW}, \pm 0.01 \mathrm{~g})$ and digestive tract weight $(\mathrm{DW}, \pm 0.01 \mathrm{~g}$ ) were measured and the gonadosomatic index (GSI) and digestosomatic index (DSI) were estimated according to the formulas GSI = $100 \times$ GW/BW and DSI $=100 \times$ DW/BW, respectively. Oocyte diameter (OD, $\pm 1 \mu \mathrm{m})$ was calculated according to Yamamoto et al. (1974). The sex ratio of the eel was skewed towards the female in the Kaoping River (Tzeng et al. 2002a). Males were thus collected less frequently than females. A total of 96 females were randomly selected for this study.

Otolith preparation for $\mathrm{Sr}$ :Ca ratio analysis. Sagittal otoliths, the largest of the 3 pairs of otoliths in the inner ear of the 61 females, were used for Sr:Ca ratios and age determination. $\mathrm{Sr}$ and $\mathrm{Ca}$ concentrations in otoliths were measured using an electron probe microanalyzer (EPMA, JEOL JXA-8900R). The procedure for preparation of the otolith for $\mathrm{Sr}$ :Ca ratio analysis followed that of previous studies (Tzeng et al. 1994, 1997). Sr and $\mathrm{Ca}$ concentrations in the otolith were measured from the primordium to the otolith edge at an interval of $20 \mu \mathrm{m}$, with an electron beam diameter of $5 \mu \mathrm{m}$. The accelerating voltage of EPMA was set at $15 \mathrm{kV}$ and probe current at $5 \mathrm{nA}$. After microchemistry analysis, the otolith was polished to remove the carbon layer, and etched for 1 to 2 min with $5 \%$ EDTA to reveal the annular marks for age determination.

Design of oligonucleotide primers. Oligonucleotides, used as PCR primers for amplification of the
PRL cDNA of the Japanese eel, are listed below and shown in Fig. 2.

Primer 1. Sense primer (SP) of prolactin: 5'-GACAAGCTTCACTCTCTCAGCAC-3';

Primer 2. Antisense primer (ASP) of prolactin: 5'-GAAACAGGACAGCAGGAAGTAGAA-3';

Primer 3. SP for 3'-RACE: 5'-TCCAAGGCGGCGACCTCGGCAGC-3';

Primer 4. ASP for 5'-RACE: 5'-GGAAGCCGTGTGGCACATGGAG-3';

Adapter primer (AP) for 3'-RACE: 5'-GGCCACGCGTCGACTAGTACTTTTTTTTTTTTTTTTT-3';

Abridged universal amplification primer (AUAP) for $3^{\prime}$ RACE: 5'-GGCCACGCGTCGACTAGTAC-3';

Abridged anchor primer (AAP) for 5'-RACE: 5' GGCCACGCGTCGACTAGTACGGGIIGGGIIGGGIIG-3', where I is the base inosine;

SP of $\beta$-actin subunit: 5'-GCTGTCCCTGTATGCCTCTGG-3';

ASP of $\beta$-actin subunit: 5'-GTCAGGATCTTCATGAGGTAGTC-3'.

The SP $\left(5^{\prime} \rightarrow 3^{\prime}\right)$ and ASP $\left(3^{\prime} \rightarrow 5^{\prime}\right)$ were designed based on the European eel Anguilla anguilla from the conserved coding region of the teleost PRL sequences retrieved from GenBank. The $\beta$-actin sequence of the Japanese eel was cloned in our laboratory.

RT-PCR and rapid amplification of cDNA ends (RACE). Total RNA was extracted from pituitary glands using the total RNA miniprep system kit (Viogene). The concentration and quality of the extracted RNA was measured at A260/A280 nm (Kontron Spectrophotometer, UVIKON 810). Complementary DNA was synthesized using the oligo- $\mathrm{d}(\mathrm{T})_{18}$ primer $(100 \mathrm{ng})$ and the moloney murine leukemia virus reverse transcriptase (MMLV-RT) (Stratagene) following instructions recommended by the manufacturer.

PCR was performed in $50 \mu \mathrm{l}$ final volumes with $2.5 \mathrm{U}$ Taq DNA polymerase (Gibco BRL) using Primers 1 and 2 (100 ng for each). After an initial 3 min denaturing step at $94^{\circ} \mathrm{C}, 35$ cycles of amplification were performed using a cycle profile of $94^{\circ} \mathrm{C}$ for $1 \mathrm{~min}$, $62^{\circ} \mathrm{C}$ for $40 \mathrm{~s}$, and $72^{\circ} \mathrm{C}$ for $1 \mathrm{~min}$. Elongation was extended to $10 \mathrm{~min}$ at $72^{\circ} \mathrm{C}$ after the last cycle. The PCR products were sequenced commercially (Mission Biotech) by the BigDye terminator cycle sequencing ready kit and analyzed on polyacrylamide gels with an ABI 377 automated sequencer (Perkin-Elmer Applied Biosystems). The remaining $5^{\prime}$ and $3^{\prime}$ untranslated terminal region (UTR) sequences were obtained using the RACE kit (Gibco $\mathrm{BRL})$, performed according to the manufacturer's instructions.
Fig. 2. Anguilla japonica. Procedures of RT-PCR sequencing of prolactin cDNA from pituitary glands of the Japanese eel. Numbers of primers indicate the corresponding oligonucleotides, listed in 'Materials and methods' 
Transcript levels of PRL mRNA in different developmental stages. Since the amount of total RNA of individual pituitaries, extracted using the total RNA purification kit, was not sufficient for northern blot analysis, RT-PCR and real-time quantitative PCR were thus chosen for PRL mRNA analysis. Total RNA (1 $\mu \mathrm{g}$ for each batch) from wild female pituitaries of yellow ( $\mathrm{n}=17$, divided into 4 batches), pre-silver $(n=9$, divided into 3 batches), and silver ( $\mathrm{n}=9$, divided into 3 batches) Japanese eels, collected between 2000 and 2001, was reverse-transcribed as described. PCR was then performed at $50 \mu \mathrm{l}$ final volume using an aliquot of the RT reaction and Primers 1 and 2. As a control in the RTPCR reactions, $\beta$-actin was amplified simultaneously. An optimal PCR amplification cycle (25 cycles) was chosen to observe the different cDNA levels based on parallelism of different PCR cycles $(15,20,25$, and 30 cycles). The results were normalized with data from densitometric scanning of a constitutively expressed protein $\beta$-actin. PCR products were analyzed by $2.5 \%$ agarose gel electrophoresis. To confirm the quantitative validity of RT-PCR product, 2 batches of the RT reaction for each stage were tested for real-time quantitative PCR using a fluorescence dye, SYBR Green 1, monitored during amplification (Morison et al. 1998).

Statistical analysis. Data was analyzed using the statistic software SPSS. Differences in the morphometric indexes as well as the transcript levels of PRL mRNA among eel stages were examined by ANOVA followed by Tukey's HSD multiple range test (Winer 1971). Differences were considered significant at $\mathrm{p}<0.05$.

\section{RESULTS}

\section{Comparison of age, size, and morphometric indices among different eel stages}

The mean age, TL, and BW of the female Japanese eels were significantly larger in the pre-silver/silver than yellow eel stages (Table 1). The mean GSI and OI of the females increased, while mean DSI decreased significantly during silvering (Table 1). The development of ovaries in relation to GSI, OI and DSI was similar to the previous study (Han et al. 2003). Briefly, the yellow eel stage contained mainly Stage 2 (chromatin nucleolus stage) oocytes. In the pre-silver eel stage, the oocytes grew rapidly and were mainly in Stage 3 (peri-nucleolus stage), and the first oil drops became apparent in the oocyte periphery. In the silver eel stage, the oocytes continued to grow until the oil drops accumulated and filled the whole cytoplasm. The oocytes were mainly in Stage 4 (oil-drop stage).

\section{Sequence analysis of the Japanese eel PRL gene}

The partial PRL cDNA was amplified from pituitary glands of Japanese eels by RT-PCR using Primers 1 and 2, which was found to be a single band in $2.5 \%$ agarose gel, and the sequenced amino acid agreed with other PRL peptides, as processed by the BLAST program of the National Center for Biotechnology Information. The remaining cDNA sequences were determined using 3 '-RACE and 5'-RACE kits. The acquired PRL cDNA of the Japanese eel (GenBank Accession No. AY158009) was 676 bp in total length, consisting of $34 \mathrm{bp}$ of the 5'UTR, $630 \mathrm{bp}$ of the coding region, and $12 \mathrm{bp}$ of partial 3'UTR (Fig. 3). The length of the 3'UTR of the Japanese eel prolactin hormone was estimated to be around $450 \mathrm{bp}$ long, based on the PCR product band (data not shown), similar to that of the European eel. However, for some unknown reason, we could not obtain the complete nucleotide sequence behind the poly G region (Fig. 3). The coding region encoded a proprotein of 209 amino acids, which contained a putative signal peptide of 24 amino acids and a mature peptide of 185 amino acids (Fig. $3)$. The amino-acid sequence identities between Japanese and European eels was $96.2 \%$, with only 8 residues difference within a 209 amino acids proprotein. The PRL sequence identities of the Japanese eel

Table 1. Anguilla japonica. Age, total length (TL), body weight (BW), ocular index (OI), digestosomatic index (DSI), gonadosomatic index (GSI), and oocyte diameter (OD) in different stages of female Japanese eels; data are mean \pm SD (range). Tukey's HSD: $\mathrm{p}<0.05$

\begin{tabular}{|lccrl|}
\hline & Yellow $(\mathrm{Y})$ & Pre-silver $(\mathrm{P})$ & Silver (S) & Tukey's HSD \\
\hline Age $(\mathrm{yr})$ & $5.0 \pm 0.3(3.0-9.0)$ & $6.3 \pm 0.4(4.5-9.5)$ & $6.7 \pm 0.3(4.0-10.0)$ & $\mathrm{Y}<\mathrm{P}=\mathrm{S}$ \\
TL $(\mathrm{cm})$ & $50.7 \pm 1.1(36.4-61.5)$ & $61.9 \pm 1.5(50.4-70.9)$ & $63.1 \pm 1.5(47.0-75.6)$ & $\mathrm{Y}<\mathrm{P}=\mathrm{S}$ \\
BW $(\mathrm{g})$ & $187.3 \pm 16.5(57.2-371.4)$ & $411.9 \pm 41.5(182.6-702.0)$ & $447.4 \pm 38.9(189.5-829.3)$ & $\mathrm{Y}<\mathrm{P}=\mathrm{S}$ \\
OI & $3.36 \pm 0.06(2.62-4.89)$ & $4.48 \pm 0.10(3.15-5.31)$ & $5.42 \pm 0.13(3.82-7.88)$ & $\mathrm{Y}<\mathrm{P}<\mathrm{S}$ \\
DSI $(\%)$ & $1.71 \pm 0.10(1.18-2.63)$ & $1.35 \pm 0.08(0.91-1.65)$ & $0.47 \pm 0.08(0.24-0.99)$ & $\mathrm{Y}>\mathrm{P}>\mathrm{S}$ \\
GSI $(\%)$ & $0.32 \pm 0.02(0.06-0.49)$ & $0.59 \pm 0.03(0.36-0.85)$ & $1.42 \pm 0.11(0.84-2.43)$ & $\mathrm{Y}<\mathrm{P}<\mathrm{S}$ \\
OD $(\mu \mathrm{m})$ & $70.2 \pm 2.1(50-90)$ & $109.8 \pm 2.4(90-130)$ & $151.1 \pm 10.2(130-225)$ & $\mathrm{Y}<\mathrm{P}<\mathrm{S}$ \\
$\mathrm{n}$ & 63 & 15 & 18 & \\
\hline
\end{tabular}




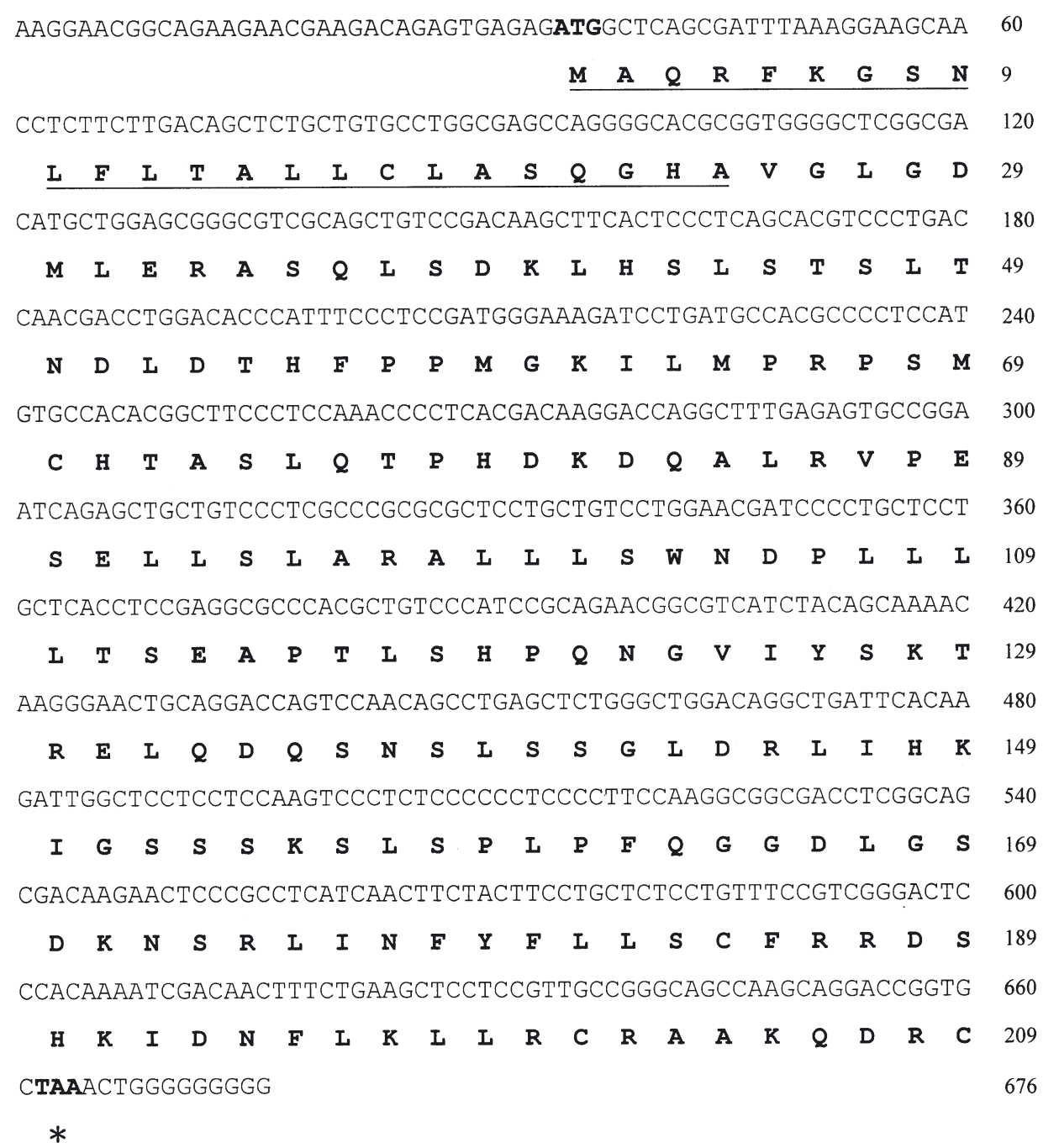

Fig. 3. Anguilla japonica. Nucleotide and deduced amino acid sequences of the Japanese eel prolactin hormone. In the righthand column, the upper numbers refer to the nucleotide sequence and the lower numbers refer to the amino acid sequence. The start (ATG) and stop (TAA, indicated by asterisk) codons are designated by bold fonts. The putative signal peptide is underlined

to other teleosts, except the European eel, ranges between 56.5 and $71.2 \%$, but the sequence identities markedly decline to between 32.7 and $36.1 \%$ when compared with the bullfrog, chicken, and human PRLs.

\section{Sr:Ca ratios in otoliths of the eels}

The life history scan of Sr:Ca ratios in the otolith of a 4 yr old female silver eel is shown in Fig. 4A. The $\mathrm{Sr}: \mathrm{Ca}$ ratios increased from the primordium with a peak 60 to $100 \mu \mathrm{m}$ from the primordium, which corresponded to the timing of metamorphosis from leptocephalus to glass eel. Beyond the metamorphosis check (MC), the otolith Sr:Ca ratios decreased rapidly until the elver check (EC), which was deposited when the glass eel met freshwater in the estuary. The otolith $\mathrm{Sr}$ :Ca ratios decreased to less than 4.0\% between Ages 1 and 3, then gradually increased from $4.0 \%$ to more than $8.0 \%$. This indicated that the eel migrated to freshwater after the elver stage and then migrated back to the high salinity seawater after Age 3. The eel otolith growth rate was estimated to be 120 to $140 \mu \mathrm{m} \mathrm{yr} \mathrm{y}^{-1}$ after Age 3, and the time needed to deposit an electron-beam spot interval was approximately half a month. Because the last spot was very close to the otolith edge, the values of the $\mathrm{Sr}$ :Ca ratios measured thus represent about the last 1 mo environmental history of the eel. 

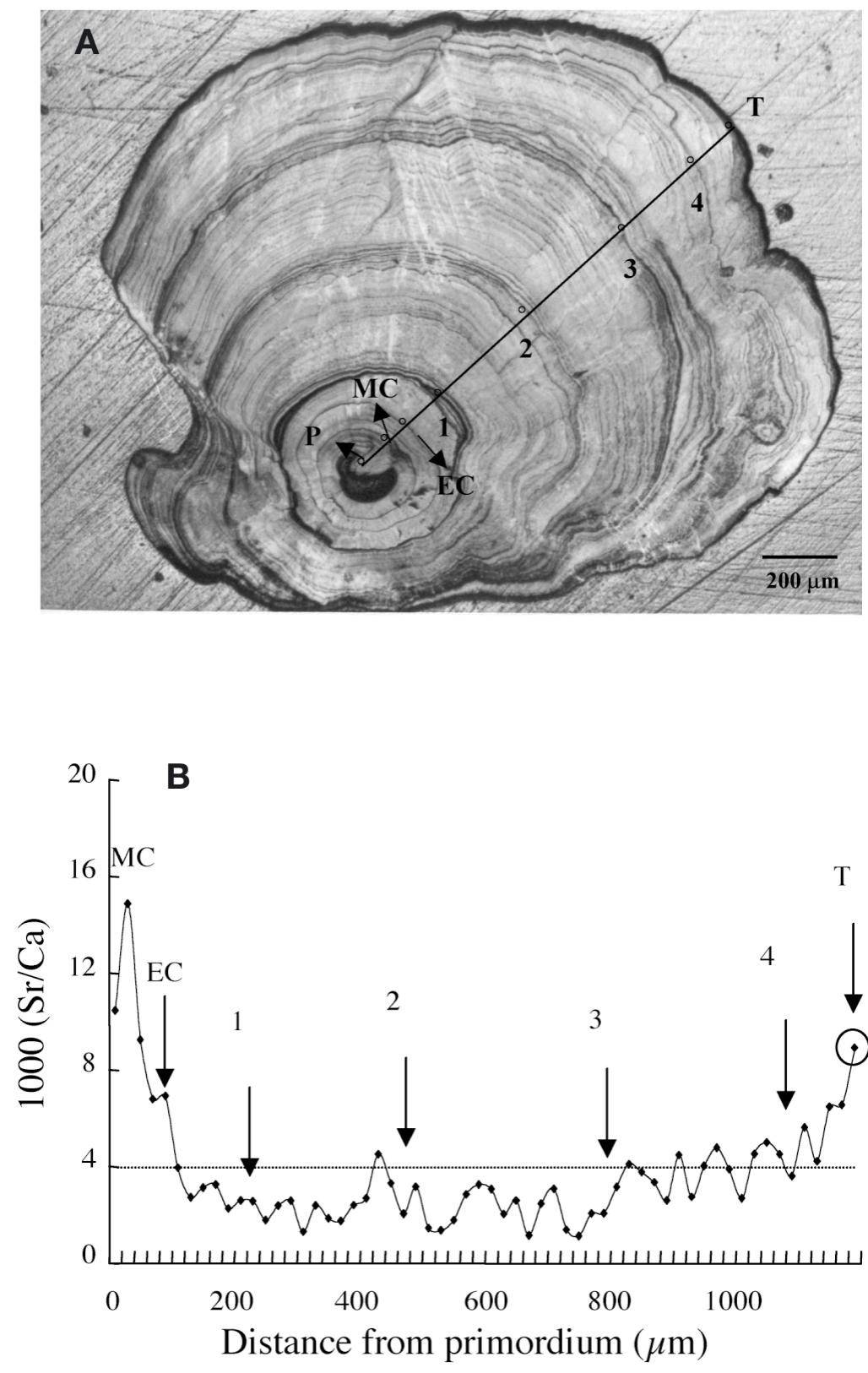

Fig. 4. Anguilla japonica. Eel otolith and associated Sr:Ca ratio analysis. (A) Annuli in the otolith of a silver female Japanese eel (total length [TL] $470 \mathrm{~mm}$; body weight [BW] $190 \mathrm{~g}$; $\mathrm{P}$, primordium; MC, metamorphosis check; EC, elver check; numerals 1 to 4, annuli; T, edge of the otolith). (B) Life history scan of the $\mathrm{Sr}$ :Ca ratios from primordium to otolith edge of the eel
The mean Sr:Ca ratios from EC to the otolith edge of the female eels were not significantly different among different stages $(F=1.26<$ $F_{0.05,60}=3.16, \mathrm{p}=0.29$ ) (Table 2). However, the mean Sr:Ca ratios at the otolith edge of the females significantly increased from yellow to silver stages $\left(F=4.60>F_{0.05,60}=3.16\right.$, $\mathrm{p}=0.014$ ) (Table 2), but not significant between yellow and pre-silver stages (Table 2). The otolith Sr:Ca ratio of $4 \%$ was a criterion to distinguish the freshwater and seawater eels (Tzeng et al. 2002b, 2003). The increase in $\mathrm{Sr}$ :Ca ratios in otolith edges from yellow to pre-silver and silver stages implied that the Japanese eels migrated from low- to highsaline water during silvering.

\section{Variation of PRL mRNA expression with developmental stages}

The PRL mRNA levels significantly decreased during eel silvering $(F=21.47>$ $F_{0.05,16}=3.74, \mathrm{p}<0.001$, Fig. 5). A representative real-time quantitative PCR for PRL mRNA expressions at different eel stages is shown in Fig. 5A. The calculated mRNA levels of PRL mRNA expression at different developmental stages are comparable to the corresponding mRNA levels estimated by the RT-PCR analysis.

\section{DISCUSSION}

Suzuki et al. (1991a) indicated that there are 2 variants of the eel PRLs purified by the HPLC method, and both variants have a molecular weight of $22 \mathrm{kDa}$ and are highly homologous in the amino acid sequences based on the partially determined N-terminal sequences (Suzuki et al. 1991a). In the present study, we cloned one form of the PRL cDNA. The other PRL cDNA or protein form remains to be investigated. The amino acid

Table 2. Anguilla japonica. Sr:Ca ratios (\%) in the inner part (elver check-edge) and at the edge of otoliths in different stages of female Japanese eels; data are mean \pm SD (range). Tukey's HSD: $\mathrm{p}<0.05$; ns: not significant

\begin{tabular}{|lcccc|}
\hline & Yellow $(\mathrm{Y})$ & Pre-silver $(\mathrm{P})$ & Silver $(\mathrm{S})$ & $\mathrm{T}$ \\
\hline Inner part & $3.4 \pm 0.14(1.8-5.0)$ & $3.4 \pm 0.31(2.3-4.4)$ & $3.9 \pm 0.5(1.8-5.9)$ & $\mathrm{ns}$ \\
Edge & $3.4 \pm 0.2(0.8-9.4)$ & $4.2 \pm 0.5(2.8-6.1)$ & $5.1 \pm 0.8(1.6-8.4)$ & $\mathrm{Y}<\mathrm{S}$ \\
$\mathrm{n}$ & 46 & 6 & 9 & \\
\hline
\end{tabular}


sequences of the eel PRLs differ, as do other teleosts, from bullfrog, chicken, and human PRLs in that disulfide loop is absent from the $\mathrm{N}$-terminal region of the mature peptide (Suzuki et al. 1991a). The percentage identities of the PRL peptide sequence are also markedly higher among teleosts in comparison to those between teleosts and tetrapods. Such findings demonstrate that a high degree of diversity exists in the PRL peptide sequence between teleosts and tetrapods. The evolutionary and physiological meanings remain to be investigated.

Previous studies have shown that the $\mathrm{Sr}$ :Ca ratios in the otoliths of Japanese eels are positively correlated with ambient salinities (Tzeng 1996, Kawakami et al. 1998, Secor \& Rooker 2000). Thus, a temporal change of Sr:Ca ratios in eel otoliths is used to reconstruct the environmental history of the eel migration between freshwater and seawater (Tzeng et al. 1997, 2002b, 2003, Tsukamoto et al. 1998, Tsukamoto \& Arai 2001). The Sr:Ca ratios from EC to the otolith edges of the yellow females ranged from 1.8 to $5.0 \%$ in the present study (Table 2), indicating that a part of yellow eels may have stayed in the seawater before silvering. The mean Sr:Ca ratios from EC to the otolith edges were not significantly different among yellow, pre-silver, and silver stages. This is because the duration of eel silvering is short, and the difference in $\mathrm{Sr}$ :Ca ratios among eel stages cannot be discriminated by the mean $\mathrm{Sr}: \mathrm{Ca}$ ratios. The change in $\mathrm{Sr}: \mathrm{Ca}$ ratios among stages was only detectable by comparing the ratio at the otolith edges of the eels, which significantly increased from yellow to silver stages (Table 2). This indicates that the eel migrates from freshwater to the high saline waters during silvering. The $\mathrm{Sr}: \mathrm{Ca}$ ratios at the otolith edges of the silver eels ranged from 1.6 to $8.4 \%$, in which the minimal values of the $\mathrm{Sr}$ :Ca ratios were similar to those of yellow eels in the freshwater (Table 2). Since the Sr:Ca ratios in the otolith edges represent about the last 1 mo of salinity history of the eel, these silver eels with low $\mathrm{Sr}$ :Ca ratios at the otolith edges may indicate that the eel just migrates from the low- to high-saline water region of the estuary, which may lead to small otolith deposition, and thus no high Sr:Ca ratios were detected.

The PRL mRNA expression also suggested the movement of eels from freshwater to seawater during silvering. The transcript levels of the PRL mRNA in the eel
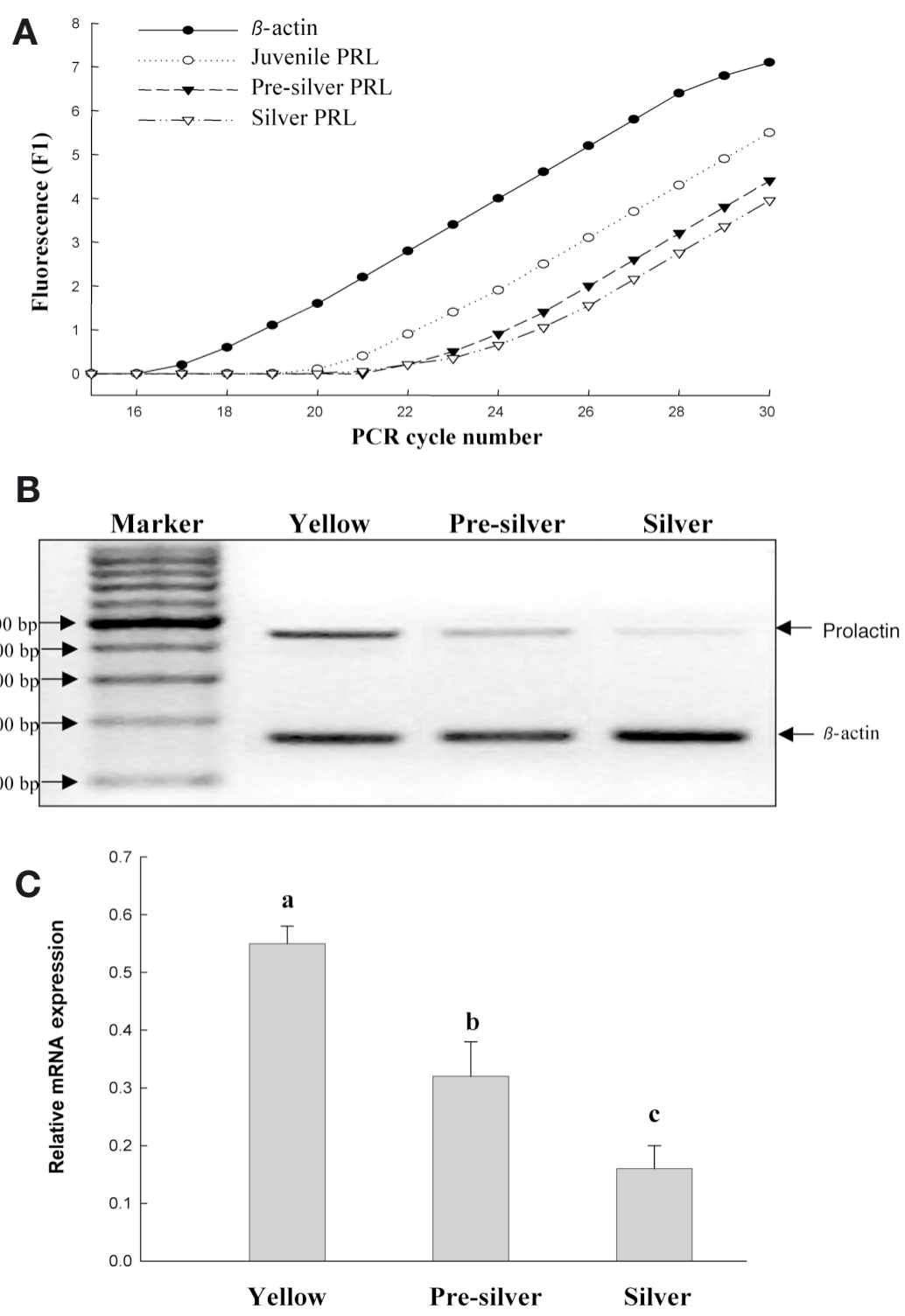

Fig. 5. Anguilla japonica. Expressions of the prolactin mRNA in the Japanese eel pituitaries from different developmental stages. (A) Representative real-time quantitative PCR for PRL mRNA expressions at different eel stages. (B) Total RNA prepared from each stage was reverse transcribed and subjected to PCR. $\beta$-actin was used as a control in each line. (C) The band intensities of PRL mRNA from yellow, pre-silver, and silver eel stages were analyzed by Kodak Digital Science ID image analysis software (V.3.0). Different letters above the histograms indicate that the differences are statistically significant $(p<0.001)$

pituitaries strongly reflect the effect of environmental salinity, with a significantly decreasing trend from yellow to pre-silver and from pre-silver to silver eel stages $(p<0.001$, Fig. 5). The change of the PRL mRNA expression is sharper than the change of $\mathrm{Sr}$ :Ca ratios at the otolith edge in response to the salinity shift during eel silvering. The reason may be that the required response time of the PRL mRNA expression levels to 
salinity transfer is only approximately $1 \mathrm{~d}$ (Suzuki \& Hirano 1991, Suzuki et al. 1991b).

In the present study, the yellow and silver stage eels were caught and exposed to the same salinity regimes for about half a day before being sacrificed. However, the silver eels showed a lower PRL expression value than the yellow ones (Fig. 5). There are 2 possible explanations. First, in eels, although the relationship between salinity and PRL expression is valid, the lower PRL transcript levels in silver eels than in yellow eels may also include a maturity response in addition to a salinity response. However, when the freshwaterreared yellow eels were induced to become silver eels by repeated injection of human chorionic gonadotropins, no significant difference was observed for the expression of PRL mRNA levels between the yellow and silver eels (Y. S. Han et al. unpubl. data). This may partially exclude the maturation-related change in the PRL expression of the eel. Alternatively, the more possible reason may be that the exposure time for the eels in the same salinity regime was not long enough to eliminate the different expression patterns of the PRL mRNA between yellow and silver eels. That is, the true difference of PRL mRNA expression between yellow and silver eels may be even larger than the observed value in the present study.

In conclusion, we have identified the complete PRL amino acid sequences of the Japanese eel, and validated their movement from low- to high-saline waters in the estuary during silvering by examining the $\mathrm{Sr}$ :Ca ratios at the otolith edges and the pituitary PRL mRNA expression levels. The $\mathrm{Sr}$ :Ca ratios in otoliths can reveal the whole migratory environmental history of the eel, while the PRL mRNA expression can detect their short-term salinity history.

Acknowledgements. This study was financially supported by the Council of Agriculture, Executive Yuan, Taiwan, ROC (90AS-1.4.5-FA-F1-36 and 91AS -2.5.1-FA-F1-8). The authors are grateful to Mr. G. H. Cheng for sample collection and data processing, to Mr. J. T. He for gonadal histology, and to Mr. B. M. Jessop for reviewing the manuscript.

\section{LITERATURE CITED}

Aoyama J, Hissmann K, Yoshinaga T, Sasai S, Uto T, Ueda H (1999a) Swimming depth of migrating silver eels Anguilla japonica released at seamounts of the west Mariana Ridge, their estimated spawning sites. Mar Ecol Prog Ser 186:265-269

Aoyama J, Sasai S, Miller MJ, Shinoda A, Nakamura A, Kusaka H, Tsukamoto K (1999b) The first tracking studies on yellow and silver eels Anguilla japonica in the estuarine habitat. J Taiwan Fish Res 9:153-160

Benjamin M, Baker BI (1976) Ultrastructural studies on prolactin and growth hormone cells in Anguilla pituitaries in vitro. Cell Tissue Res 174:547-564
Campana SE (1999) Chemistry and composition of fish otoliths: pathways, mechanism and applications. Mar Ecol Prog Ser 188:263-297

Clarke WC, Bern HA (1980) Comparative endocrinology of prolactin. In: $\mathrm{Li} \mathrm{CH}$ (ed) Hormonal proteins and peptides, Vol 8. Academic Press, New York, p 105-197

Han YS, Liao IC, Huang YS, He JT, Chang CW, Tzeng WN (2003) Synchronous changes of morphology and gonadal development of silvering Japanese eel Anguilla japonica. Aquaculture 219:783-796

Ingleton PM, Baker BI, Ball JN (1973) Secretion of prolactin and growth hormone by teleosts pituitaries in vitro. I. Effect of sodium concentration and osmotic pressure during short-term incubations. J Comp Physiol 87: $317-328$

Jessop BM (1987) Migrating American eels in Nova Scotia. Trans Am Fish Soc 116:161-170

Jessop BM, Shiao JC, Iizuki Y, Tzeng WN (2002) Migratory behaviour and habitat use by American eels Anguilla rostrata as revealed by otolith microchemistry. Mar Ecol Prog Ser 233:217-229

Kawakami Y, Mochioka N, Morishita K, Tajima K, Nakagawa H, Toh H, Nakazona A (1998) Factors affecting otolith strontium/calcium ratios in Anguilla japonica elvers. Environ Biol Fish 52:299-303

Kelly SP, Chow INK, Woo NYS (1999) Effects of prolactin and growth hormone on strategies of hypoosmotic adaptation in a marine teleost, Sparus sarba. Gen Comp Endocrinol 113:9-22

Kozaka T, Fujii Y, Ando M (2003) Central effects of various ligands on drinking behavior in eels acclimated to seawater. J Exp Biol 206:687-692

Lokman PM, Young G (1998a) An intersexual migratory (silver) longfinned New Zealand eel and its gonadal response to treatment with salmon pituitary homogenate. J Fish Biol 52:547-555

Lokman PM, Young G (1998b) Gonad histology and plasma steroid profiles in wild New Zealand freshwater eel (Anguilla dieffenbachia and A. australis) before and at the onset of the natural spawning migration. Females. Fish Physiol Biochem 19:325-338

Matsui I (1972) Unagigaku: eel biology. Kosei-sha KoseiKaku, Tokyo

McCleave JD, Arnold GP (1999) Movements of yellow- and silver-phase European eel (Anguilla anguilla L.) tracked in the western North Sea. ICES J Mar Sci 56:510-536

Morrison TB, Weis JJ, Wittwer CT (1998) Quantification of low copy transcripts by continuous SYBR Green 1 monitoring during amplification. BioTechniques 24:954-962

Nagahama Y, Nishioka RS, Bern HA, Gunther RL (1975) Control of prolactin secretion in teleosts, with special reference to Gillichthys mirabilis and Tilapia mossambica. Gen Comp Endocrinol 25:166-188

Otake T, Ishii T, Nakahara M, Nakamura R (1994) Drastic changes in otolith strontium/calcium ratios in leptocephali and glass eels of Japanese eel Anguilla japonica. Mar Ecol Prog Ser 112:189-193

Pankhurst NW (1982) Relation of visual changes to the onset of sexual maturation in the European eel Anguilla anguilla (L.). J Fish Biol 21:127-140

Pankhurst NW, Sorensen PW (1984) Degeneration of the alimentary tract in sexually maturing European Anguilla anguilla (L.) and American eel Anguilla rostrata (Le Sueur). Can J Zool 62:1143-1149

Quérat B, Cardinaud B, Hardy A, Vidal B, D'Angelo G (1994) Sequence and regulation of European eel prolactin mRNA. Mol Cell Endocrinol 102:151-160 
Radtke RL, Shafer DJ (1992) Environmental sensitivity of fish otolith microchemistry. Aust J Mar Freshw Res 43: 935-951

Secor DH, Rooker JR (2000) Is otolith strontium a useful scalar of life cycles in estuarine fishes? Fish Res 46:359-371

Sorensen PW, Pankhurst NW (1988) Histological changes in the gonad, skin, intestine and olfactory epithelium of artificially matured male American eels, Anguilla rostrata (Le Sueur). J Fish Biol 32:297-307

Suzuki R, Hirano T (1991) Development of a homologous radioimmunoassay for eel prolactin. Gen Comp Endocrinol 81:403-409

Suzuki R, Yasuda A, Kondo J, Kawauchi H, Hirano T (1991a) Isolation and characterization of Japanese eel prolactins. Gen Comp Endocrinol 81:391-402

Suzuki R, Kaneko T, Hirano T (1991b) Effects of osmotic pressure on prolactin and growth hormone secretion from organ-cultured eel pituitary. J Comp Physiol 161B: 147-153

Tesch FW (1977) The eel: biology and management of anguillid eels. Chapman \& Hall, London

Tsukamoto K (1992) Discovery of the spawning area for Japanese eel. Nature 356:789-791

Tsukamoto K, Arai T (2001) Facultative catadromy of the eel Anguilla japonica between freshwater and seawater habitats. Mar Ecol Prog Ser 220:265-276

Tsukamoto K, Nakai I, Tesch WV (1998) Do all freshwater eels migrate? Nature 396:635-636

Tzeng WN (1996) Effects of salinity and ontogenetic movements on strontium: calcium ratios in the otoliths of the Japanese eel, Anguilla japonica Temminck \& Schlegel. J Exp Mar Biol Ecol 199:111-122

Tzeng WN, Tsai YC (1994) Changes in otolith microchemistry of the Japanese eel, Anguilla japonica, during its migra-

Editorial responsibility: Otto Kinne (Editor),

Oldendorf/Luhe, Germany tion from the ocean to the rivers of Taiwan. J Fish Biol 45: 671-683

Tzeng WN, Wu HF, Wickström H (1994) Scanning electron microscopic analysis of annulus microstructure in otolith of European eel Anguilla anguilla. J Fish Biol 45:479-492

Tzeng WN, Severin KP, Wickström H (1997) Use of otolith microchemistry to investigate the environmental history of European eel Anguilla anguilla. Mar Ecol Prog Ser 149: $73-81$

Tzeng WN, Lin HR, Wang CH, Xu SN (2000a) Differences in size and growth rates of male and female migrating Japanese eels in Pearl River, China. J Fish Biol 57:1245-1253

Tzeng WN, Wang CH, Wickström H, Reizenstein M (2000b) Occurrence of the semi-catadromous European eel Anguilla anguilla (L.) in the Baltic Sea. Mar Biol 137:93-98

Tzeng WN, Han YS, He JT (2002a) The sex ratios and growth strategies of wild and captive Japanese eels Anguilla japonica. In: Small B, MacKinlay D (eds) Developments in understanding fish growth. Int Cong Biology of Fish. University of British Columbia, Vancouver, p 25-42

Tzeng WN, Shiao JC, Iizuka Y (2002b) Use of otolith Sr:Ca ratios to study the riverine migratory behaviors of Japanese eel Anguilla japonica. Mar Ecol Prog Ser 245:213-221

Tzeng WN, Iizuka Y, Shiao JC, Yamada Y, Oka HP (2003) Identification and growth rates comparison of divergent migratory contingents of Japanese eel (Anguilla japonica). Aquaculture 216:77-86

Westin L (1990) Orientation mechanisms in migrating European silver eel (Anguilla anguilla): temperature and olfaction. Mar Biol 106:175-179

Winer B (1971) Statistical principles in experimental design. McGraw-Hill, New York

Yamamoto K, Oomori M, Yamauchi K (1974) Oogenesis of the Japanese eel. Bull Jpn Soc Sci Fish 40:9-15

Submitted: January 31, 2003; Accepted: June 13, 2003

Proofs received from author(s): September 1, 2003 